\title{
The Bert W. Davis Site (41HP3) on the South Sulphur River in Hopkins County, Texas
}

Timothy K. Perttula

Heritage Research Center, Stephen F. Austin State University

Follow this and additional works at: https://scholarworks.sfasu.edu/ita

Part of the American Material Culture Commons, Archaeological Anthropology Commons, Environmental Studies Commons, Other American Studies Commons, Other Arts and Humanities Commons, Other History of Art, Architecture, and Archaeology Commons, and the United States History Commons

Tell us how this article helped you.

This Article is brought to you for free and open access by the Center for Regional Heritage Research at SFA ScholarWorks. It has been accepted for inclusion in Index of Texas Archaeology: Open Access Gray Literature from the Lone Star State by an authorized editor of SFA ScholarWorks. For more information, please contact cdsscholarworks@sfasu.edu. 


\section{The Bert W. Davis Site (41HP3) on the South Sulphur River in Hopkins County,}

Texas

\section{Creative Commons License}

\section{(c) (1) (8)}

This work is licensed under a Creative Commons Attribution-NonCommercial 4.0 International License 


\title{
The Bert W. Davis Site (41HP3) on the South Sulphur River in Hopkins County, Texas
}

\author{
Timothy K. Perttula
}

\section{INTRODUCTION}

The Bert W. Davis site in the South Sulphur River valley in East Texas (Figure 1) was investigated by archaeologists from the University of Texas (UT) in 1919 and 1934, because an aboriginal cemetery had been exposed by plowing and later looting. The UT work consisted of a reconnaissance by J. E. Pearce in September 1919 and trenching by A. T. Jackson and crew in July 1934 (Jackson 1934). A small assemblage of artifacts were recovered by UT during this work, but the collection (now at the Texas Archeological

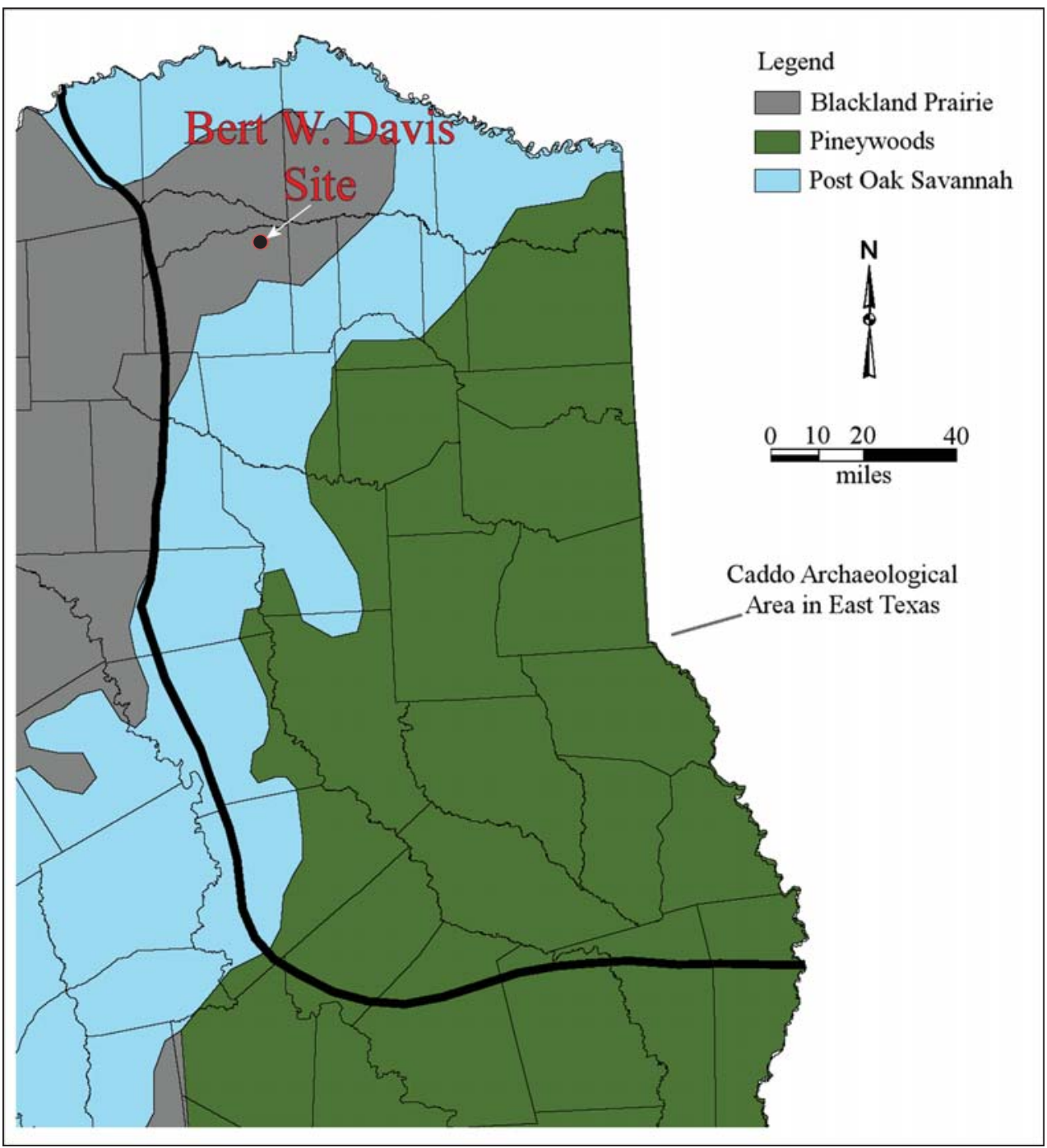

Figure 1. Location of the Bert W. Davis site in East Texas. 
Research Laboratory at UT) had never been fully studied or the results of the work published. This was unfortunate because it appears that the Bert W. Davis site is virtually a single component Woodland period site that was occupied during the early part of the period, from ca. 100 B.C. to A.D. 300. Such sites are rare in the East Texas archaeological record (e.g., Ellis et al. 2013). In this article, I discuss the analysis of the site and its distinctive artifact assemblage.

\section{SITE SETTING}

The Bert W. Davis site is situated on a sandy knoll on an alluvial terrace of the South Sulphur River, $2.5 \mathrm{~km}$ south of an old channel of the river (Figure 2). The knoll measures ca. 63 x $55 \mathrm{~m}$ north-south and east-west, about 0.9 acres in size, and had extensive midden deposits and an aboriginal cemetery.

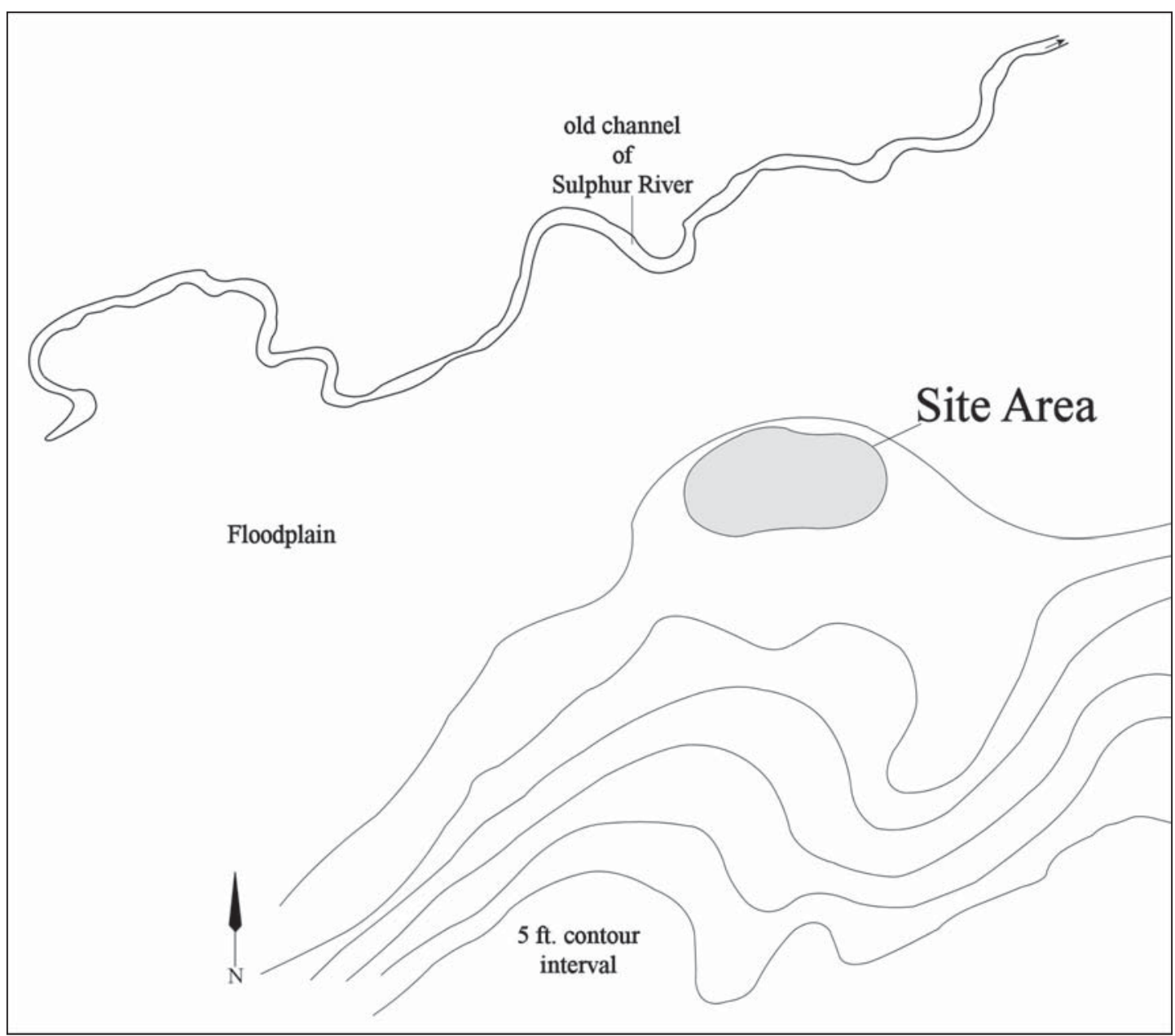

Figure 2. The location of the Bert W. Davis site in the South Sulphur River valley in Hopkins County, Texas.

In 1918, the plowing of the Davis farm exposed the aboriginal cemetery. The local lessee, J. R. Stephens, then excavated in the knoll and uncovered 10 burials. According to J. E. Pearce, who visited the site in 1919, the funerary offerings with the burials included four ceramic vessels and two celts. Pearce attempted to secure the collection, but in 1920 , the collection was obtained by a representative from Texas A\&M University. ${ }^{1}$ Pearce did not provide any details about the funerary offerings other than one vessel was a plain water bottle and the other three vessels were fragmentary. 
In 1934 A. T. Jackson and a UT crew returned to the Bert W. Davis site. Jackson (1934) noted that there were midden deposits across the knoll that contained charcoal, animal bones, mussel shells, etc. The UT crew trenched the midden, eventually excavating $156 \mathrm{~m}$ of trenches at the site, but no burials or significant features were identified during the work. The midden ranged from ca. $35-110 \mathrm{~cm}$ in depth.

Jackson (1934) did provide further details about the burials that had been excavated by Stephens (and perhaps others) at the Bert W. Davis site. According to Jackson, between 16 and 18 burials were excavated there, and they were found at shallow depths in the midden $(30-50 \mathrm{~cm} \mathrm{bs})$; this suggests the burials were interred near the end of the occupation, or at least the end of the midden accumulation on the knoll. A few of the burials were accompanied by ceramic vessels, and one burial was accompanied by a tubular pipe. Some of the burials were in extended supine positions, with their heads facing to the northeast, and in one area, there were five burials interred with the head of one deceased individual placed between the feet of another deceased individual (Jackson 1934:22).

\section{ARTIFACT ASSEMBLAGE}

The assemblage of artifacts from the Bert W. Davis site is far from extensive; the UT crew did not screen any of the archaeological deposits at the site. The assemblage includes only 35 chipped stone tools, two ground stone tools, a deer bone ornament, and 93 ceramic rim and body sherds.

\section{Chipped Stone Tools}

The chipped stone tools from the Bert W. Davis site include end and side scrapers $(n=2)$, final stage biface fragments $(n=2)$, and several kinds of dart points, a dart point preform, and fragments $(n=32)$. The tools are made from local quartzite raw materials ( $n=27,75$ percent of the tools), as well as Red River gravel cherts ( $n=7,19$ percent), and novaculite $(n=2,5.6$ percent); the quartzite was used exclusively in the manufacture of dart points.

The two end-side scrapers are made from a reddish-brownish-gray chert and a gray novaculite. They have steeply retouched and used edges on non-cortical flakes; they range from 7.5-7.9 $\mathrm{mm}$ in thickness.

The final stage bifaces are distal fragments ranging between 6.4-6.7 $\mathrm{mm}$ in thickness. One was made of a dark gray chert and the other may have been made of a whitish-gray Frisco chert, likely available in Red River gravels.

Among the dart points are three quartzite blade fragments and a novaculite medial fragment, a quartzite Gary dart point preform, as well as Calf Creek ( $n=1)$, Edgewood $(n=1)$, Trinity $(n=1)$, Kent $(n=6)$, and Gary $(\mathrm{n}=18)$ type points. The Calf Creek point is made from a Red River gravel chert, and has a resharpened blade, a long parallel stem with a flat base, deep basal notches, and long downward-pointing barbs. The Calf Creek points date to about 5800-6000 cal. years B.P. (see Lohse et al. 2014), in the Middle Archaic period in East Texas. The bulbous-stemmed quartzite Trinity dart point likely marks some use of the site during the Late Archaic period (ca. 5000-2500 years B.P.) (Turner et al. 2011:166).

The other 25 dart points - the Gary, Kent, and Edgewood types - in the Bert W. Davis collection are indicative of a Woodland period occupation. These points are overwhelmingly made from local quartzite (88 percent); one Kent point is made from a light gray chert, while two Gary points are made from a brown chert and a gray chert. The stem width of the Gary points ranges from 9.9-17.9 mm, with a mean stem width of $13.1 \mathrm{~mm}$. This suggests that these Gary points are Gary, var. Camden specimens (see Schambach 1982), and that they date to after ca. A.D. 200. 


\section{Ground Stone Tools}

There are several ground stone tools in the lithic assemblage from the Bert W. Davis site. This includes three quartzite polished pebbles, a grooved quartzite pebble $(63 \times 39 \times 26 \mathrm{~mm}$ in length, width, and thickness) with six diagonal grooved lines cut into several surfaces, and two celt fragments made from Ouachita Mountains greenstone and Hatton tuff. The first celt is the butt end of the tool, while the other is the bit end and mid-section (Figure 3). The bit width on this celt is $31.0 \mathrm{~mm}$, and along the mid-section the celt is 48.0 $\mathrm{mm}$ in width.

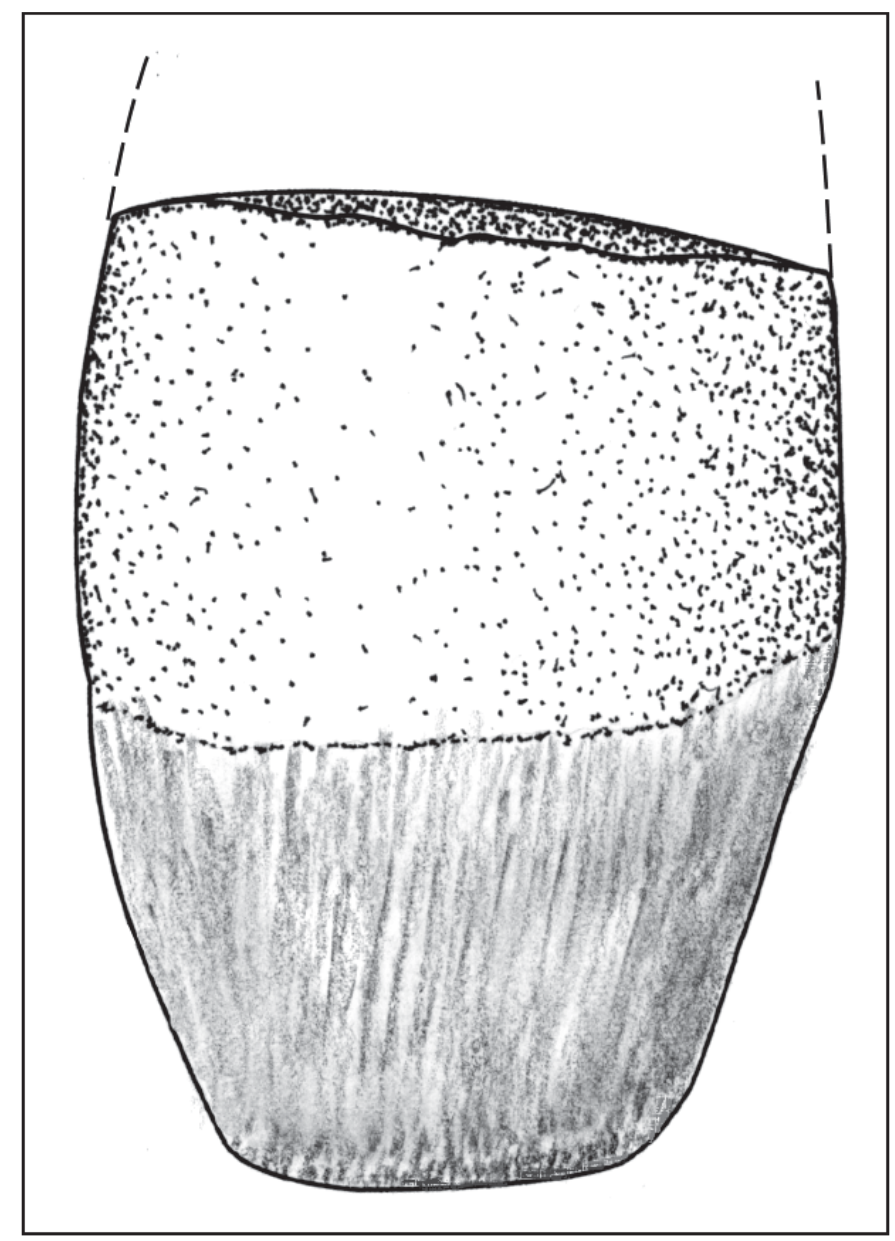

Figure 3. Celt fragment from the Bert W. Davis site.

\section{Ceramic Sherds}

The ceramic sherd assemblage from the site is comprised of 88 plain body and base sherds and five decorated rim and body sherds. Several of the sherds have lower Mississippi Valley (LMV) stylistic elements of ceramic types dating as a group between ca. 100 B.C. and A.D. 300, but instrumental neutron activation analysis and petrographic analysis of the sherds would need to be conducted to definitely determine that they are from LMV vessels rather than "locally made variants of recognizable LMV types" (Ellis et al. 2013:218).

The plain sherds are grog-tempered. Several body sherds are thick (ranging from 10.0-10.7 $\mathrm{mm}$ ) and are probably from Williams Plain jars.

One bone-tempered body sherd has a single straight incised line. A grog-tempered rim (direct rim and a rounded, exterior folded lip) has a row of tool punctates on the folded over vessel lip (Figure 4a). Another 
grog-tempered rim (direct rim and rounded lip) has broad U-shaped diagonal to curvilinear incised lines as well as a vertical row of triangular-shaped tool punctations (Figure 4b). The stylistic elements on this sherd resemble several varieties of Marksville Incised, including var. Spanish Fort, var. Sunflower, and var. Yokena (Brown 1998:16), which were manufactured in the LMV between ca. 100 B.C. and A.D. 300, in the early Woodland period in East Texas.

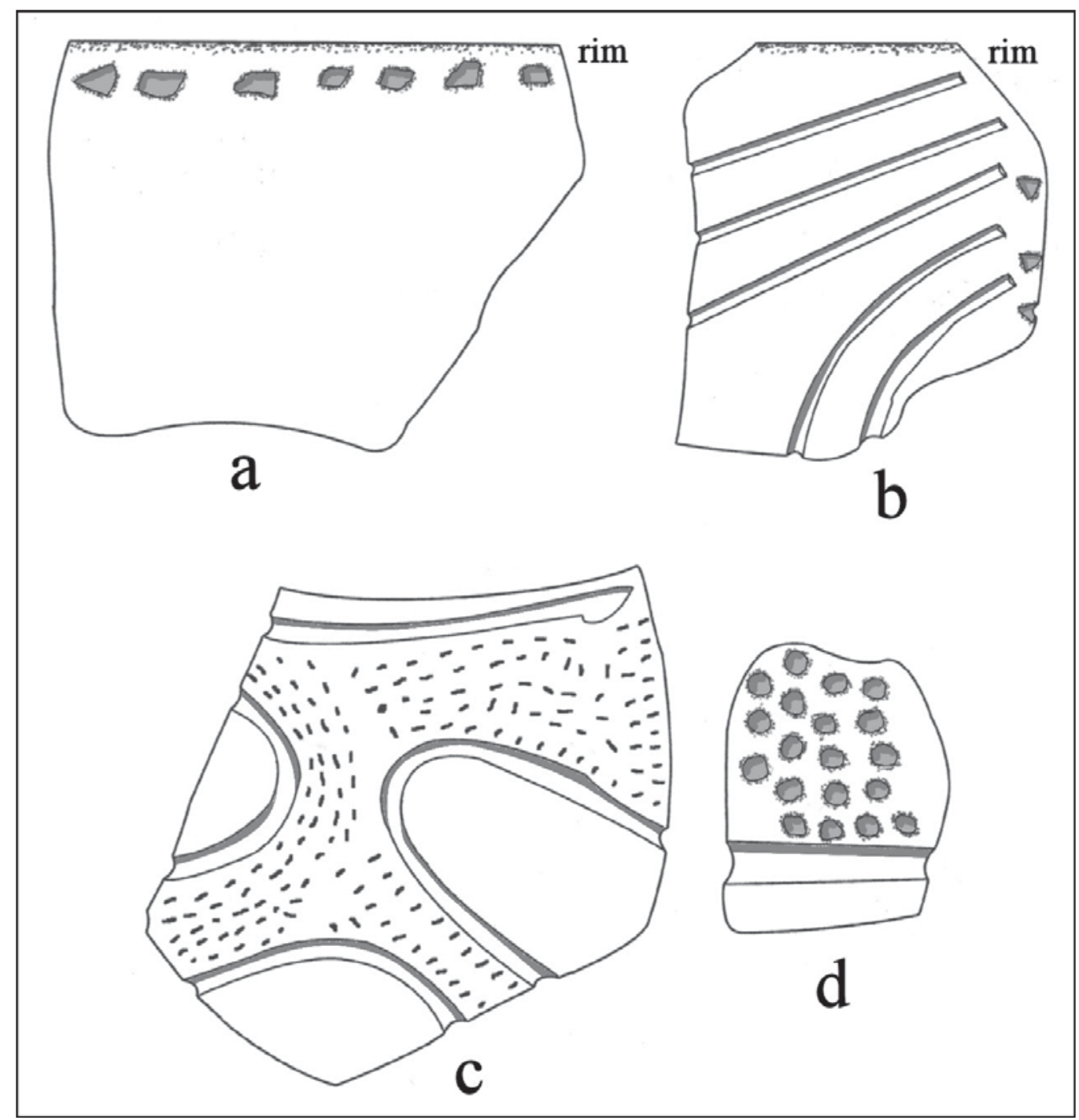

Figure 4. Decorated ceramic sherds from the Bert W. Davis site: a, tool punctated rim sherd; $b$, Marksville Incised rim sherd; c, Marksville Stamped rim sherd; d, Churpa Punctated body sherd.

There is also a grog-tempered rim (direct rim and a rounded lip) with broad U-shaped curvilinear incised lines and areas between the incised lines filled with rows of dentate stamping (see Figure 4c). It is identified as Marksville Stamped, var. Troyville (Brown 1998:33), and the vessel from which it derived likely dates from ca. A.D. 100-300.

The last decorated sherd in the Bert W. Davis ceramic assemblage is a grog-tempered body sherd from a Churupa Punctated, var. Churupa vessel (see Brown 1998:24). The sherd has a single straight, broad Ushaped incised line adjacent to rows of hemi-conical punctations (see Figure 4d). In the LMV, this variety of Churupa Punctated dates from ca. A.D. 100-300. 


\section{Modified Deer Bone}

There is a single modified deer phalange in the collection. The $40.0 \mathrm{~mm}$ long phalange has a drilled hole near one end (Figure 5), suggesting it was suspended on a necklace or bracelet. The drilled hole is approximately $6.5 \mathrm{~mm}$ in diameter.

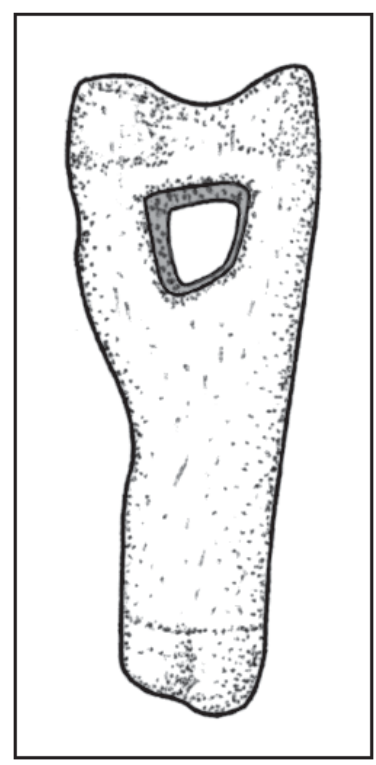

Figure 5. Drilled deer phalange from the Bert W. Davis site.

\section{SUMMARY AND CONCLUSIONS}

Except for two dart points of Middle Archaic and Late Archaic period age from the Bert W. Davis site, the archaeological deposits at this site on the South Sulphur River in East Texas appear to represent a single component Woodland period site. This component is estimated to date between ca. 100 B.C. and A.D. 300 . The site had an extensive midden and a cemetery with an estimated 16-18 individuals. Where information is available, the burials were interred in an extended position, and were accompanied by a few funerary offerings: four ceramic vessels, two celts, and a tubular pipe.

The collections at TARL from the Bert W. Davis site are dominated by Gary dart points made from local lithic raw materials and sherds from plain grog- and bone-tempered vessels. Three of the grog-tempered sherds have stylistic affiliations with Lower Mississippi Valley (LMV) ceramic vessels made during the Marksville period, including rims that closely resemble Marksville Incised, var. Spanish Fort, var. Sunflower, and var. Yokena, Marksville Stamped, var. Troyville, and Churupa Punctated, var. Churupa. Such LMVaffiliated ceramic sherds are only rarely found on East Texas Woodland period sites.

\section{ACKNOWLEDGMENTS}

I would like to thank Jonathan Jarvis at TARL for facilitating the study of the collections and records from the Bert W. Davis site. Lance Trask prepared the figures in this article. 


\section{END NOTE}

1. As of this writing, the collection from the site that was obtained in 1920 by Texas A\&M University has not been identified in the currently maintained collections at the university.

\section{REFERENCES CITED}

Brown, I. W.

1998 Decorated Pottery of the Lower Mississippi Valley: A Sorting Manual. Mississippi Archaeological Association and Mississippi Department of Archives and History, Jackson.

Ellis, L. W., R. Rogers, C. Wallace, D. Burden, A. Burden, A. Kalter, M. Smith, and C. Heiligenstein

2013 Data Recovery at the Hawkwind Site (41HS915), Harrison County, Texas. Archeological Studies Program Report No. 138. Archeological Studies Program, Environmental Affairs Division, Texas Department of Transportation, Austin.

Jackson, A. T.

1934 Burial Site and Midden, Bert W. Davis Plantation Located 1 1/2 Miles South of old channel of South Sulphur River, three miles north of Nelta and 19 miles N.E. of Sulphur Springs, Hopkins County, Texas, Excavated 7/13/34 to 7/18/34. MS on file, Texas Archeological Research Laboratory, The University of Texas at Austin.

Lohse, J. C., S. L. Black, and L. M. Cholak

2014 Toward an Improved Archaic Radiocarbon Chronology for Central Texas. Bulletin of the Texas Archeological Society 85:251-279.

Schambach, F. F.

1982 An Outline of Fourche Maline Culture in Southwest Arkansas. In Arkansas Archeology in Review, edited by N. L. Trubowitz and M. D. Jeter, pp. 132-197. Research Series No. 15. Arkansas Archeological Survey, Fayetteville.

Turner, E. S., T. R. Hester, and R. L. McReynolds

2011 Stone Artifacts of Texas Indians. Taylor Trade Publishing, Lanham, Maryland. 